\title{
An Overview of the Application of Maqasid Al-Shariah into Cartilage Tissue Engineering
}

Muhammad Aa'zamuddin Ahmad Radzi ${ }^{1}$, Abdurezak Abdulahi Hashi ${ }^{2}$, Munirah Sha'ban ${ }^{3}$

${ }^{1}$ Department of Biomedical Science, Kulliyyah of Allied Health Sciences, International Islamic University Malaysia, Kuantan, ${ }^{2}$ Department of Biotechnology, Kulliyyah of Science, International Islamic University Malaysia, Kuantan, ${ }^{3}$ Department of Physical Rehabilitation Sciences, Kulliyyah of Allied Health Sciences, International Islamic University Malaysia,Kuantan.

\section{ABSTRACT}

Tissue engineering, being part of regenerative medicine approaches has been researched and applied to treat the articular cartilage diseases. It offers benefit to humankind by improving healthcare economics, better treatment options and quality of life among the osteoarthritic patients. It is felt that this promising field requires Islamic essences to be addressed to its concepts and practices. The paper begins with the discussion of the potential of cartilage tissue engineering in overcoming the harms that may impact the healthcare stakeholders (patients, providers, medical professionals, researchers and healthcare authorities). This will be followed by deliberations based on the Maqasid al-Shariah (five higher objectives of Islamic Law), namely, safeguarding of faith, soul, wealth, mind, and offspring. The deliberations illustrate a general idea of cartilage tissue engineering concept and practices in relation to what Islam champions. Islamic Law is comprehensive and incorporates the moral propositions to the medical discipline. It is presented that every legal ruling in Islam has a function to achieve the benefit to human beings or to protect against harm. The application of Maqasid al-Shariah can serve as a practical framework in healthcare setting especially cartilage tissue engineering. It is hoped that this paper will open further discourses to facilitate for a decree by the relevant authority pertaining to the experimentation and practice of tissue engineering, particularly cartilage tissue engineering.

KEYWORDS: Osteoarthritis, Cartilage, Tissue Engineering, Islamic Perspective, Maqasid al-Shariah.

\section{INTRODUCTION}

Articular cartilage acts as a load-bearer in human synovial joints. Unlike other tissues, it has little capacity to restore itself because of its aneural, avascular and alymphatic natures. Affliction on articular cartilage is irreversible and may lead to osteoarthritis (OA), a complex multifactorial degenerative condition of the joint.

\section{Osteoarthritis}

OA can be regarded as a progressive joint disease caused by a failure in joint damage repair. It is one of the main causes of disability in adults. ${ }^{1}$ OA has been considered as one of the most commonly diagnosed medical conditions in the United States (US). This disorder has affected millions of people worldwide, and it is estimated that 27 million adults have symptomatic $O A$ in the US alone. ${ }^{2}$ It is anticipated that OA prevalence to be doubled over the next several decades. ${ }^{3,4}$ Despite its high prevalence, there is no available effective treatment

Munirah Sha'ban

Department of Physical Rehabilitation Sciences, Kulliyyah of Allied Health Sciences,

International Islamic University Malaysia,

Kuantan Campus.

Email: munirahshaban@iium.edu.my to prevent or slow the disease progression. ${ }^{5}$

OA greatly affect the health-related quality of life among osteoarthritic patients by causing limitation in mobility and higher mortality and morbidity. ${ }^{6-8}$ Lee, Lee, and Park ${ }^{9}$ say as cited from a study, ${ }^{10}$ the muscle weakness in lower limb and limitation in physical activity are due to pain which are common complications in the knee and hip OA. The condition is also associated with old age. With age, the quality of life of elderly people, especially the OA patients, must be enhanced beyond the simple goal of survival.

Currently, therapeutic options for OA include pharmacological and nonpharmacological treatments for symptomatic relief of OA. ${ }^{11}$ The drug therapy includes simple analgesic, non-steroidal anti-inflammatory drugs (NSAIDs), cyclo-oxygenase-2 (COX-2) inhibitors, glucosamine and diacerein. Alternatively, surgery will be considered if the patient's quality of life and daily activities are significantly affected even after the above mentioned medical therapies have been prescribed. The available surgical interventions include drilling, microfracture, mosaicplasty and autologous chondrocyte implantation $(\mathrm{ACl}) .{ }^{1}$ All the available options may act only as a temporary measure. ${ }^{12}$ If those treatments are no longer effective, the patients may have to undergo total joint replacement surgery. 


\section{Cartilage Tissue Engineering}

The ideal solution for treating $\mathrm{OA}$ by constructing native articular cartilage is still being explored. It can be noted that tissue restoration activities can be traced back since ancient times. ${ }^{13}$ Nowadays, medical practitioners and scientists are given more alternatives to treat the affected articular surface as the restorative techniques, including cell-based therapy and transplant, are being developed. This gives rise to tissue engineering (TE) field whereby the main principle behind this technique is to repair, regenerate and restore the normal functions of human tissues or organs. Increasing trend of research in cartilage TE may give an answer to cure the OA. ${ }^{14}$

Cartilage TE researchers are resorting to tissue engineering principles to repair and restore instead of replacing the cartilage with prosthetics. The technology has attracted healthcare stakeholders including osteoarthritic patients, medical service providers, medical professionals, researchers and healthcare authorities. There are three main elements in applying the principle of cartilage TE which are the cell sources, biomaterial scaffolds, and signaling molecules. The combination of these three elements (also known as TE triad) will form the "cell-scaffold" construct. Taking the cells from a patient, the construct will then be implanted back into the damaged area in the same patient's knee. The technique is known as autologous transplantation.

It is felt that this promising field requires Islamic essences to be addressed in its concepts and practices. Since calls for Shariah (Islamic Law) compliance in the biomedical application are growing, it would be justified to explore and deliberate on cartilage TE from the Islamic perspective ${ }^{15,16}$ especially within the context of Maqasid al-Shar'iah (higher objectives of Islamic Law). Maqasid al-Shar'iah leads to the fulfillment of Maslahah (benefits) and prevents Mafsadah (mischief) based on divine revelation (Qu'ran and Prophetic tradition). The emphasis will be given on the role of cartilage TE in addressing the harms that affect the healthcare stakeholders. A holistic understanding that underlines the Maqasid alShar'iah should be presented in relation to these issues.

This paper distances itself from providing an ultimate Islamic decree or legal maxim in the application of cartilage TE in the healthcare setting. Subsequently, the paper instigates a discussion on the application of the Maqasid alShar'iah into cartilage TE in addressing OA.

\section{A SUMMARY OF MAQASID AL-SHAR'IAH}

Islam is a comprehensive way of life and its foundational goals address the whole aspects of individual's life and society, in this world and the Hereafter. A comprehensive understanding of
Maqasid al-Shariah may serve each individual and society in terms of justice, brotherhood and social welfare. ${ }^{17}$

From the historical perspective, Maqasid al-Shariah was originally introduced in the eighth century by Imam al-Syafi'e in his writings al-Risalah. This is mentioned by Ibn Subki as well as al-Qarafi (a Maliki jurist in the thirteenth century) in Nafa'is al-Usul fi Syarh al-Mahsul. ${ }^{18}$ In eleventh century, al-Juwayni reconstruct the concept of Maqasid al-Shariah. Then, al-Ghazali in his writings Shifa' al-Ghalil and al-Mustasfa, had further discussed and refined the Maqasid al-Shariah approach. Izz al-Din Abd alSalam further explored the approach in the thirteenth century. Influenced by Izz al-Din al-Salam and al-Ghazali, al-Shatibi further detailed out the concept of Maqasid al-Shariah in al-Muwafaqat in the fourteenth century. al-Juwayni was said to be the first to classify Maqasid al-Shariah into three levels. ${ }^{19,20}$

The levels are Dharuriyat (necessities), Hajiyat (needs), and Tahsiniyat (luxuries). Dharuriyat was considered essential matters for human survival and spiritual wellbeing. The failure to address the Dharuriyat would precipitate chaos in the community. The Dharuriyat level can be further classified into safeguarding one's faith, soul, wealth, mind, and offspring. This paper will be focusing on the five foundational goals of Islamic Law as introduced by the earlier scholars. Maqasid al-Shariah has to be considered as a whole and not in parts in order to reflect the holistic view of Islam. It is authors' opinion that Maqasid al-Shariah could be utilized to form the practical framework of cartilage TE to safeguard the Diin/faith, Nafs/soul, $\mathrm{Mal} /$ wealth, 'Aql/mind, and Nasl/offspring.

The Application of Maqasid Al-Shariah In Cartilage The Concept And Practices

The ensuing discussions describe the application of five elements of Maqasid al-Shariah on the medical management of $\mathrm{OA}$ in relation to the use of TE.

\section{Protection of Faith}

OA of knee and hip is one of the leading causes of disability worldwide. It was ranked as the $11^{\text {th }}$ highest contributor to global disability as stated in the Global Burden of Disease study in 2010. ${ }^{21,22}$ OA can significantly reduce the ability for physical activities $^{23,24}$ including those in the religious ritual. Seen from an Islamic perspective, the limitation on a patients' physical functioning, mobility or stamina may significantly affect the way they perform the religious physical rituals such as Solah (daily prayers) and Hajj (pilgrimage). Taking prayers, for example, Ruku' (bow down), Tashahhud (sitting between two prostrations), and Sujud (prostrations) are used to praise, glorify and humble oneself in front of Allah. These are among the vital parts of the five daily prayers which deemed obligatory for every Muslim. The daily prayers are the manifestations of a Muslim's spiritual wellbeing in 
strengthening individual faith and submission to Allah.

Kasule $^{25}$ states that medical treatment can be utilized to protect the faith by promoting good health and well-being. Cartilage TE has the potential to restore the native cartilage structures and functions of OA patients. The application of the technology may preserve the faith of Muslim individual through reinstating his physical rituals. Besides that, Muslim medical practitioners and scientists are using their contemplating faculty and skills in order to seek for best treatment and help the others. They are assisting the Muslims to remain steadfast in performing religious obligations to Allah. ${ }^{15}$ Applying cartilage TE may instill the moral norms of Ihsan (beneficence and benevolence) as Islam requires in the process of healing and remedy. ${ }^{26}$ The clinical application and research of cartilage TE, with good intentions, may serve to protect the faith of Muslims patients.

\section{Protection of Soul}

According to World Health Organization (WHO), quality of life (QOL) is "individuals' perceptions of their position in life in the context of the culture and value systems in which they live and in relation to their goals, expectations, standards and concerns". ${ }^{27}$ The QOL can be classified into nonhealth-related quality of life (NHRQL) and healthrelated quality of life (HRQL). The HRQL constitute general wellbeing including the components that can directly affect individual's physical, psychological and mental health. ${ }^{10,28}$ Not only the pain and disability affect the QOL of patient itself but other family members as well. Inability to do physical activity will further deteriorate the health and lead to other chronic diseases such as diabetes mellitus and hypertension. ${ }^{29,30}$ Thus, the patient's QOL must be addressed properly by healthcare authorities in order to reduce the risk of mortality.

OA patients were reported to be concerned about the possible side effects of drugs such as NSAIDs. ${ }^{11}$ Gastrointestinal bleeding due to the treatment with NSAIDs is not counted as one of the mortality associated with OA. ${ }^{31}$ With that, OA deaths are likely highly underestimated. ${ }^{32}$ The indirect effect of taking drugs to relieve the pain associated with $\mathrm{OA}$ has not been given much attention. One has to note that the drugs may inflict side effects to patients if they neglect the proper drug administration and management. Poor understanding in consuming the drugs may cost patients' life. Applying the cartilage TE to save the patient's knee may prevent the heavy dependence on drugs which may lower the risk of mortality.

Matters of life and death are in the hands of Allah alone. Kasule ${ }^{25}$ mentioned that even medicine cannot prevent or postpone the death itself. However, medicine can help to preserve the life by ensuring the patient physiological functions are well sustained. Until the time of quietus, cartilage TE may act as a measure to sustain QOL of the osteoarthritic patients. Cartilage TE has the potential to nullify or reduce the risks caused by drugs prescription by directly treating the side of effect or injury. ${ }^{15}$ Successful restoration of cartilage can enhance the $\mathrm{QOL}$ of the patients and reduce the mortality and morbidity caused by OA.

\section{Protection of Wealth}

In 2012, Chen, Gupte, Akhtar, Smith, and $\mathrm{Cobb}^{33}$ has mentioned that "Costs for topical and oral NSAIDs were estimated to be £19.2 million and £25.65 million, respectively. The cost of hip and knee replacements was estimated to exceed $£ 850$ million, arthroscopic surgery for osteoarthritis was estimated to be $£ 1.34$ million. Indirect costs from $O A$ caused a loss of economic production over $£ 3.2$ billion, £43 million was spent on community services and £215 million on social services for osteoarthritis".It can be inferred that OA has contributed to the growing financial burden on the healthcare system. One can anticipate that the cost to treat OA will increase in the future. Protection of wealth in Maqasid al-Shariah involves both human and material resources. An individual's health is correlated with the community health. Healthy citizens may contribute more to the society in terms of financial growth. ${ }^{25}$

OA results in large indirect costs to society, mainly impelled by decreased productivity. ${ }^{34}$ These indirect costs, combined with expenditure in OA management and particularly total joint arthroplasty ${ }^{35}$ create a huge economic burden. ${ }^{22} \mathrm{~A}$ study has shown that musculoskeletal pain and osteoarthritis had affected both female and male workers. ${ }^{10}$ This may influence their work performance as they are trying to cope with the pain. Both employee and employer are affected by this medical condition which may impose stress on both parties. Osteoarthritic workers would be having low levels of productivity due to inefficiency caused by pain. Decreased productivity in an organization will lead to low profitability.

If the cartilage TE can be implemented accordingly, it has the chance to offer a better treatment option to the stakeholders. Financial dependency on pharmacological and nonpharmacological treatments for symptomatic relief, and also the surgery can be controlled in long run. Besides that, the authorities' spending on healthcare sectors can be of lesser burden with healthier people in the country. The application of cartilage TE in treating $\mathrm{OA}$ has the potential to contribute in preserving nation's economy.

\section{Protection of Mind}

OA may cause detrimental effects on quality of life, work participation, weight gain, physical activity, fatigue, sleep, anxiety, and depression. ${ }^{36-41}$ Osteoarthritic patients are considered to have a peripheral disease. The pain they experience is 
accounted by nociceptive damage at the joint level. ${ }^{42}$ This can greatly affect the mind of the osteoarthritic patient considered they are dealing with pain in their daily lives.

A study has shown that OA can be associated with short sleep duration. ${ }^{43}$ It was suggested that the pain caused by the disease consequently disrupt the sleep patterns of the arthritic patients. ${ }^{44}$ This can further cause great disparity in patient's mental health. Disturbed sleep pattern can affect one's judgment, work performance, mood, and safety. ${ }^{45}$ Chronic pain may result in psychological distress such as anxiety and depression. In the long run, pain puts much stress on the brain and causing cognitive issues like low mood, difficulty with memory or concentration. ${ }^{46}$

Safeguarding the mind by removing stress and restoring intellectual and emotional functions can be done through the application of physical treatment. ${ }^{25}$ The concept of maintaining the stable state of mind can be applied in cartilage TE by reducing or eliminating the pain inflicted by $O A$ condition. ${ }^{15}$ The patients' mental capacity could be restored and preserved since elements associated with anxiety, depression, and stress could be reduced by applying the technology.

\section{Protection of Offspring}

The discussion on offspring or lineage in this paper is focusing on the impact of OA on sexual behavior. A study done on the patients waiting for total hip (THR) or knee (TKR) replacement has shown poor scores in HRQL index on sexual activity. ${ }^{23}$ This indicates that $\mathrm{OA}$ has a direct impact on the intimate relationship between married couples which may influence the lineage of a family.

It is stated that there are several ways that arthritis can affect sexual activity ${ }^{47}$ :

1.General wellbeing and mood are affected which lead to low sexual drive.

2.Swollen joints may affect self-esteem.

3.Fatigue caused by arthritis can lower the sexual drive.

4.Painful joints make it difficult in certain position.

5.Arthritis may lead to a dry vagina.

In Islam, there are specific and special obligations for Muslims to bear offspring for the continuity of the society. A healthy community is important in building a human civilization that can maintain the values of morality, justice, and freedom. ${ }^{25} \mathrm{OA}$ as one of the musculoskeletal disorders may cause an adverse effect on reproductive capacity to the patient. Physical inability due to severe hip and knee pain, coupled with psychological disturbances associated with OA can affect intimacy between the spouses. Low sexual frequencies may reduce the chances to bear the offspring. ${ }^{15}$ Sexual satisfaction may be significantly affecting the spouses which may lead to an affair and unlawful sexual relation. It may disturb the lineage of progeny in a family. It is hoped that cartilage TE with the potential to repair the cartilage may restore the intimate relationship between husband and wife.

\section{Harm Reduction in Cartilage TE}

It can be appreciated that cartilage TE is worth to be explored by Muslims in treating the OA. However, there are technical issues need to be addressed before this biomedical technology can be applied to the patient. To name a few, the issues includes cell harvesting from the patients, safety concerns of the implanted constructs and materials use, and animals utilization in proof of concept study. ${ }^{48}$ Every aspect of cartilage TE are also bound to the moral values involving patients, surgeon, researchers as well as authority. Thus, there is a need to identify the harms and come out with an effective system or framework to eliminate or reduce the harms.

A simple and general risk assessment is not possible in cartilage TE as the purposes, procedures and applications are too variable in each level of TE. Thus, there is a need for a comprehensive review to address all the issues respectively. It is noted that the role of Islamic Law is not to restrict the medical discovery, rather it may work as an approach to identify the medical benefits and meaningful aspects. The approach of Maqasid al-Shariah is very important in shaping the healthcare framework in cartilage TE. Thus, it can be conferred that the function of Maqasid al-Shariah can be used to guide the scientific directions which in line with Islamic teaching.

\section{CONCLUSION}

This paper presents a general idea of cartilage TE concept and practices in relation to what Islam champions. It is presented that every legal ruling in Islam has a function to achieve the benefit to human beings or to protect against harm. OA may cause harms in terms of disability, mortality, mental and economic instability, and also affect sexual activity. Cartilage TE, being one of the solutions in treating the OA complements the currently available treatments in managing the disease. It offers benefits if the technology can be conducted in a systematic order. However, there are still scientific and ethical challenges that surround the application of cartilage TE. The application of Maqasid alShariah in TE can serve as a practical framework to safeguard the faith, soul, wealth, mind, and offspring. It can be concluded that the treatment of OA is considered as Dharuriyat as the disease affect directly the stakeholders' well-being. The technology itself is worth to be explored and expanded to cater the OA predicament. It is hoped that this paper will open further discourses to facilitate for a decree by the relevant Islamic authority pertaining to the experimentation and practice of tissue engineering, particularly cartilage TE. 
The authors thanked the Kulliyyah of Allied Health Sciences (KAHS), International Islamic University Malaysia (IIUM), Kuantan Campus, and Tissue Engineering and Regenerative Medicine Research Team (TERT), IIUM. The authors also appreciate the thoughtful and critical review by Assistant Professor Dr. Zainul Ibrahim Zainuddin from Department of Diagnostic Imaging and Radiotherapy, KAHS, whose efforts improved the clarity and presentation of this paper. In addition, the augratitude to Ministry of Higher Education for their support and for providing MyRA Incentive Research Grant Scheme (MIRGS1301-002-0003) and Transdisciplinary Grant Scheme (TRGS16-02-003-0003) as well as Ministry of Science and Technology for Science Fund (SF14-012-0062).

\section{REFERENCES}

1. Practice Clinical Guidelines Secretariat, ed. Management Of Osteoarthritis. 2nd Edition. Putrajaya: Ministry of Health Malaysia

2. Johnson VL, Hunter DJ. The epidemiology of osteoarthritis. Best Pract Res Clin Rheumatol. 2014;28(1):5-15. doi:10.1016/j.berh.2014.01.004.

3. Centers for Disease Control and Prevention. Projected state-specific increases in selfreported doctor-diagnosed arthritis and arthritis-attributable activity limitations--United States, 2005-2030. MMWR Morb Mortal Wkly Rep. 2007;56(24):608-610.

https://www.cdc.gov/mmwr/preview/mmwrht $\mathrm{ml} / \mathrm{mm} 5617 \mathrm{a} 3 . \mathrm{htm}$.

4. Schrubbe LA, Ravyts SG, Benas BC, et al. Pain coping skills training for African Americans with osteoarthritis (STAART): study protocol of a randomized controlled trial. BMC Musculoskelet Disord. 2016;17(1):359. doi:10.1186/s12891016-1217-2.

5. Poulet B, Beier F. Targeting oxidative stress to reduce osteoarthritis. Arthritis Res Ther. 2016;18:32. doi:10.1186/s13075-015-0908-7.

6. Goh S-L, Persson MSM, Bhattacharya A, Hall M, Doherty M, Zhang W. Relative efficacy of different types of exercise for treatment of knee and hip osteoarthritis: protocol for network meta-analysis of randomised controlled trials. Syst Rev. 2016;5(1):147. doi:10.1186/s13643-016-0321-6.

7. Laslett LL, Quinn SJ, Winzenberg TM, Sanderson $\mathrm{K}$, Cicuttini $\mathrm{F}$, Jones $\mathrm{G}$. A prospective study of the impact of musculoskeletal pain and radiographic osteoarthritis on health related quality of life in community dwelling older people. BMC Musculoskelet Disord. 2012;13:168. doi:10.1186/1471-2474-13-168.

8. Centers for Disease Control and Prevention. Disabilities and Limitations. U.S. Department of Health \& Human Services.

http://www.cdc.gov/arthritis/data_statistics/d isabilities-limitations.htm. Published 2016. Accessed September 25, 2016.

9. Lee J, Lee H, Park E. Effect of Staged Education
Program for Hypertension, Diabetes Patients in a Community (Assessment of Quality of Life Using EQ-5D). J Agric Med Community Heal. 2014;39(1):37-45.

10. Hong $\mathrm{S}$, Jeong $\mathrm{H}$, Heo $\mathrm{Y}$, Chun $\mathrm{H}$, Park J, Kim D. Factors associated with health-related quality of life in Korean older workers. Ann Occup Environ Med. 2015;27:25. doi:10.1186/s40557015-0077-9.

11. Basedow M, Hibbert P, Hooper T, Runciman W, Esterman A. Australians with osteoarthritis $\square$ : satisfaction with health care providers and the perceived helpfulness of treatments and information sources. 2016:387-394.

12. Tur K. Biomaterials and Tissue Engineering for Regenerative Repair of Articular Cartilage Defects. Turkish J Rheumatol. 2009;24:206-217.

13. Meyer U. Fundamentals of Tissue Engineering and Regenerative Medicine. (Meyer U, Handschel J, Wiesmann HP, Meyer T, eds.). Berlin, Heidelberg: Springer Berlin Heidelberg; 2009. doi:10.1007/978-3-540-77755-7.

14. Rozlin AR, Muhammad Aa'zamuddin AR, Norhamiza MS, Noorhidayah MN, Munirah S. Tissue engineering of articular cartilage: From bench to bed-side. Tissue Eng Regen Med. 2015;12(1):1-11. doi:10.1007/s13770-014-90448.

15. Mohamad MY, Zainuddin ZI, Sha'ban M. The application of tissue engineering in degenerative disc disease: an Islamic perspective. Regen Res. 2014;3(1):41-51. http://irep.iium.edu.my/38812/.

16. Mustaqim M, Zarif M, Hamid A, Murad A, Fahmimdyus of $A$. The Use of Forbidden Materials in Medicinal Products: An Islamic Perspective. Middle-East J Sci Res. 2013;13:510. doi:10.5829/idosi.mejsr.2013.16.s.10022.

17. Abdulazeem A, Dusuki AW. The Challenges of Realizing Maqasid al-Shari ah in Islamic Banking and Finance. In: International Conference on Islamic Banking and Finance: "Research and Development: The Bridge between Ideals and Realities." ; 2007:1-27.

18. Al-Qarafi. Nafa'is Al-Usul Fi Syarh Al-Mahsul, Juz 4. Beirut: Dar al-Kutub al-'Ilmiyah; 2000.

19. Kamali MH. Principles in Islamic Jurisprudence. Cambridge: The Islamic Texts Society; 1991.

20. Saifuddeen SM, Rahman NNA, Isa NM, Baharuddin A. Maqasid al-Shariah as a Complementary Framework to Conventional Bioethics. Sci Eng Ethics. 2014;20(2):317-327. doi:10.1007/s11948-013-9457-0.

21. Cross $M$, Smith E, Hoy $D$, et al. The global burden of hip and knee osteoarthritis: estimates from the Global Burden of Disease 2010 study. Ann Rheum Dis. 2014;73(7):1323-1330. doi:10.1136/annrheumdis-2013-204763.

22. Flego A, Dowsey MM, Choong PFM, Moodie M. Addressing obesity in the management of knee and hip osteoarthritis - weighing in from an economic perspective. BMC Musculoskelet Disord. 2016;17(1):233. doi:10.1186/s12891 016-1087-7.

23. Hirvonen J, Blom M, Tuominen U, et al. Health- 
related quality of life in patients waiting for major joint replacement. A comparison between patients and population controls. Health Qual Life Outcomes. 2006;4:3. doi:10.1186/1477-7525-4-3.

24. Tuominen U, Blom M, Hirvonen J, et al. The effect of co-morbidities on health-related quality of life in patients placed on the waiting list for total joint replacement. Health Qual Life Outcomes. 2007;5:16. doi:10.1186/1477-7525-516.

25. Kasule $\mathrm{OH}$. Biomedical Ethics: An Islamic Formulation. J Islam Med Assoc North Am. 2010;42(March):38-40.

26. Abdurezak AH. Bioethics: A Comparative Study of Its Concepts, Issues and Approaches. Gombak: IIUM Press; 2015.

27. The WHOQOL Group. Whoqol-Bref: Introduction , Administration , Scoring and Generic Version of the Assessment. Program Ment Heal. 1996;(December):16. doi:10.1037/t01408-000.

28. Nelson EC, Wasson JH, Johnson DJ, Hays RD. Dartmouth COOP functional health assessment charts: Brief measures for clinical practice. Qual life pharmacoeconomics Clin trials. 1996;2:161-168. doi:10.1016/S01972456(97)82191-5.

29. Chadha R. Revealed aspect of metabolic osteoarthritis. J Orthop. 2016;13(4):347-351. doi:10.1016/j.jor.2016.06.029.

30. Hawker GA, Croxford R, Bierman AS, et al. Osteoarthritis-related difficulty walking and risk for diabetes complications. Osteoarthritis Cartilage. August 2016. doi:10.1016/j.joca.2016.08.003.

31. Sacks JJ, Helmick CG, Langmaid G. Deaths from arthritis and other rheumatic conditions, United States, 1979-1998. J Rheumatol.

2004;31(9):1823-1828.

http://www.ncbi.nlm.nih.gov/pubmed/1533850 7.

32. Centers for Disease Control and Prevention. Osteoarthritis (OA). http://www.cdc.gov/arthritis/basics/osteoarth ritis.htm. Accessed September 25, 2016.

33. Chen a., Gupte C, Akhtar K, Smith P, Cobb J. The Global Economic Cost of Osteoarthritis: How the UK Compares. Arthritis. 2012;2012:1-6. doi:10.1155/2012/698709.

34. OECD. Health at a Glance 2013: OECD Indicators.; 2013. doi:10.1787/health_glance2013-en.

35. Australian Institute of Health and Welfare. Health burden and work impacts of osteoarthritis.

http://www.aihw.gov.au/osteoarthritis/burden -of-disease/\#source-table1. Accessed September 25, 2016.

36. Murphy LB, Sacks JJ, Brady TJ, Hootman JM, Chapman DP. Anxiety and depression among US adults with arthritis: prevalence and correlates. Arthritis Care Res (Hoboken). 2012;64(7):968976. doi:10.1002/acr.21685.

37. Allen KD, Renner JB, Devellis B, Helmick CG, Jordan JM. Osteoarthritis and sleep: the
Johnston County Osteoarthritis Project. J

Rheumatol. 2008;35(6):1102-1107.

http://www.ncbi.nlm.nih.gov/pubmed/1848469 0.

38. Theis KA, Murphy L, Hootman JM, Wilkie R. Social participation restriction among US adults with arthritis: a population-based study using the International Classification of Functioning, Disability and Health. Arthritis Care Res (Hoboken). 2013;65(7):1059-1069. doi:10.1002/acr.21977.

39. harif B, Garner R, Sanmartin C, Flanagan WM, Hennessy D, Marshall DA. Risk of work loss due to illness or disability in patients with osteoarthritis: a population-based cohort study. Rheumatology. 2016;55(5):861-868. doi:10.1093/rheumatology/kev428.

40. Centers for Disease Control and Prevention. Arthritis as a Potential Barrier to Physical Activity Among Adults With Heart Disease --United States, 2005 and 2007.

http://www.cdc.gov/mmwr/preview/mmwrht $\mathrm{ml} / \mathrm{mm}$ 5807a2.htm. Published 2009. Accessed September 25, 2016.

41. Ackerman IN, Ademi Z, Osborne RH, Liew D. Comparison of health-related quality of life, work status, and health care utilization and costs according to hip and knee joint disease severity: a national Australian study. Phys Ther. 2013;93(7):889-899. doi:10.2522/ptj.20120423.

42. Gwilym SE, Keltner JR, Warnaby CE, et al. Psychophysical and functional imaging evidence supporting the presence of central sensitization in a cohort of osteoarthritis patients. Arthritis Care Res. 2009;61(9):1226-1234. doi:10.1002/art.24837.

43. Lee $M-S$, Shin J-S, Lee J, et al. The association between mental health, chronic disease and sleep duration in Koreans: a cross-sectional study. BMC Public Health. 2015;15:1200. doi:10.1186/s12889-015-2542-3.

44. Lima MG, Bergamo Francisco PMS, de Azevedo Barros MB. Sleep duration pattern and chronic diseases in Brazilian adults (ISACAMP, 2008/09). Sleep Med. 2012;13(2):139-144. doi:10.1016/j.sleep.2011.07.011.

45. Peri C. What Lack of Sleep Does to Your Mind. WebMD. http://www.webmd.com/sleepdisorders/features/emotions-cognitive\#1. Accessed September 25, 2016.

46. Australian Pain Management Association. Psychological Effects of Chronic Pain. https: / / www. painmanagement.org.au/2014-0911-13-35-53/2014-09-11-13-36-47/178psychological-effects-of-pain.html. Published 2014. Accessed September 25, 2016.

47. Arthritis Research UK. Will arthritis affect my sex life? http:/ / www.arthritisresearchuk.org/arthritisinformation/arthritis-and-daily-life/sex-andarthritis/will-arthritis-affect-my-sex-life.aspx. Accessed September 25, 2016.

48. Muhammad Aa'zamuddin AR, Munirah S. A Preliminary Review on Moral Challenges in Tissue Engineering. Revel Sci. 2016;6(1):17-26. 